\title{
Educating Higher Education Institutions to Support SDGs: Indonesian Case
}

\author{
Ambariyanto Ambariyanto ${ }^{1,2^{*}}$, Yos Johan Utama $^{3}$ \\ ${ }^{1}$ Universitas Diponegoro SDG Center, Universitas Diponegoro, Semarang, Indonesia \\ ${ }^{2}$ Faculty of Fisheries and Marine Science, Universitas Diponegoro, Semarang, Indonesia \\ ${ }^{3}$ Faculty of Law, Universitas Diponegoro, Semarang, Indonesia \\ Jl. Prof. Sudarto SH, Kampus Tembalang, Semarang, Indonesia
}

\begin{abstract}
Sustainable Development Goals (SDGs) have become international programs and are adopted by almost all countries in the world. All institutions at various levels and sectors in each country have developed programs to support and accelerate the achievement of the 17 goals of the SDGs, including higher education institutions. However, there are still many universities that are not fully aware of and understand this matter, even though they may carry out programs that are actually related to one or more of the goals of the SDGs. This can be seen from the limited number of universities that have SDGs Center or sustainability office. To focus more on developing programs in higher education and further increasing efforts in order to achieve these goals, educational programs for higher education institutions are needed. This effort can be made by the central government through the relevant ministries, as well as related offices at the provisional government level. In addition, there are several higher education ranking programs that have indirectly educated these higher education institutions about SDGs.
\end{abstract}

\section{Introduction}

The Sustainable Development Goals that were initiated by the UN in early 2016 with a target at the end of 2030, have now become an international program, which has been approved by almost all countries in the world (sgds.un.org). This shows how important the SDGs are to our lives, so that governments from various countries are willing to support various programs to achieve the SDG goals. The SDGs are basically a continuation of the United Nations Millennium Development Goals (MDGs) program which has eight targets and ends in 2015 [1].

\footnotetext{
* Corresponding author: ambariyanto@live.undip.ac.id
} 
To achieve the target of the SDGs by the end of 2030, all government and even private institutions are asked to play a role through the development of programs and activities, especially referring to 169 programs in the 17 goals of the SDGs. In Indonesia, the institution that plays an important role in doing this is Bappenas (National Development Planning Board), which is supported by other ministries [2].

One of the institutions that can play an important role in accelerating the achievement of the SDGs target is higher education institutions. An understanding of the principles of the SDGs needs to be given not only to the institution, but also to lecturers and students [3]. This is important to do because higher education institutions that understand this problem will come up with policies that support the achievement of these targets. For example, in the campus development process, curriculum development, and other policies can be made in line with the SDGs achievement program $[4,5]$.

In addition, higher education institutions will produce graduates who in the future have a very important role in various sectors and at various levels. These graduates will later become decision makers in their institutions, so they must understand the SDGs principles which are expected to be reflected in the policies they take [6]. This article describes the awareness of universities in Indonesia regarding SDGs and how to educate them to increase awareness and be able to apply it in their higher education policies.

\section{Indonesian Higher Education Institutions}

There are many universities in Indonesia, because this country is an archipelago with thousands of separate islands with a very large territory, with a population of approximately 260 million, with 34 provinces and 514 regencies / cities. The latest data shows that Indonesia has more than 4000 higher education institutions, both public and private, with approximately 7 million students.

The forms of higher education institutions also vary, namely universities, institutes and colleges, all of which will graduate to the bachelor, master and doctoral degrees. Besides that, there are also academies or polytechnics which are vocational schools that focus more on applied science and produce diplomas. This condition also creates a disparity concerning the quality of these higher education institutions. The central government through the Ministry of Research, Technology and Higher Education (2015-2019), which changed its name to the Ministry of Education and Culture (2019-present), has classified all universities into five clusters. This clustering was carried out primarily to provide more precise policies for each cluster

The policy of local governments, especially at the district / city level, is to have at least one higher education institution, intending to increase the education level of the population. Besides that, the central government also has a policy to make several private universities to become state universities. With such a large population, it is understandable that a lot of private parties have established higher education institutions, because of the huge demand. Each year there are more than 3.5 million high school graduates, most of whom wish to continue to higher education.

\section{SDGs at Higher Education Institutions}


The implementation of various programs and activities to achieve the SDGs targets has been carried out in many universities both abroad and in several universities in Indonesia, including Diponegoro University. There are many challenges and opportunities faced in implementing SDGs in higher education institutions [7]. The establishment of SDG Center, sustainability office or similar unit is an initial reflection of the understanding and exclusion of higher education institutions for the SDGs program.

Given that there are 17 goals in the SDGs, where almost all aspects of life are included, it is not too difficult for universities to develop programs and activities related to these goals. For example, the development of a good curriculum with a teaching and learning process and equipped with adequate facilities illustrates an effort to achieve quality education [8].

One that has been developed in many universities in the SDGs achievement program is the 17th goal, namely the Partnership of the Goals. It is very important to strengthen cooperation, especially with the government and the general public because it is the basis for achieving all goals. Through this collaboration, dialogue will be established, especially in developing various programs to achieve all the goals of the SDGs [9].

Higher education also implements SDGs in the teaching and learning process which will influence the spirit of Social Entrepreneurship in students. Thus, it is hoped that students who are aware and understand the SDGs will have a better social spirit, especially later after living in society [10]. Related to this, the process of character education for students has an important role [11].

Several problems are also faced in the implementation of the SDGS program at universities. The implementation of the SDGs program at the University of South Africa is particularly related to the fourth goal i.e. Quality Education in teaching, research, community engagement and campus operations management. The problems faced are the limitations of research funding, especially related to distance learning, and also the difficulty in involving students [3]. Reducing energy use at universities also faces obstacles, especially with the development of the teaching and learning process including research activities that require various types of equipment and facilities that continue to develop in laboratories. Especially with the many universities that have a vision to become a research university [12]. This requires additional energy. Compromise is needed related to the increasing energy needs with the resulting environmental impacts [13]. One thing that can be done is by utilizing renewable energy, such as solar cells and so on.

\section{SDGs at Higher Education Institutions}

In general, all tertiary institutions in Indonesia have run various programs related to SDGs, although most do not realize that this is part of a program that supports SDGs. At least the tertiary institution strives to carry out teaching and learning activities as best as possible with good curriculum [14], facilities that are attempted to be complete, in order to get good graduates. This is in accordance with the fourth objective, namely the Quality of Education.

In addition, programs related to poverty alleviation, gender equality, efforts to improve health, or preserving the campus environment and so on have usually been carried out. Higher education institutions that have a Medical Faculty and a Public Health Faculty have certainly carried out matters related to improving the quality of health. If they don't have related 
faculties, at least they have tried to keep the campus environment clean and healthy. This is in accordance with the third objective, namely Good Health and Wellbeing.

The new student admission program, for example, is not based on gender, but based on the results of college entrance examinations, this is in line with the fifth goal, namely Gender Equality. In general, colleges with complete management have a university asset management unit which is usually responsible for the environmental conditions of the campus including in the process of building construction, providing parks, including waste management $[15,16]$.

However, until now, there are only a limited number of universities in Indonesia that have SDG centers or sustainability offices or similar units, or SDGs report [17]. Several universities openly announce in the media about the existence of an SDG center, but some universities are not openly conveyed, especially in the media. There is a possibility that universities are not yet fully aware of and understand the SDGs, even though they have unwittingly carried out supporting programs as described above.

One of the efforts to educate higher education institutions has been carried out by the central government through Bappenas, which has conducted several SDGs socialization activities by inviting universities and local governments. In this kind of event, there are usually several universities that have SDG centers and local governments that have special SDGs programs to share experiences. Through this kind of lesson-learned program, many other universities have developed SDGs Center or sustainability office. Until now, there have been many universities in Indonesia that have such units with various forms. The central government's efforts should continue, not only through Bappenas but also through the Ministry of Education and Culture, as well as other relevant ministries. Efforts are needed to encourage all universities to develop units such as the SDG Center, or Sustainability offices or similar units. Because with this kind of center, programs related to the achievement of the SDGs can be more focused.

There are two higher education ranking programs related to the SDGs. The first is the Time Higher Education (THE) University Impact Ranking which focuses on SDGs activities. The THE ranking looks at university activities and programs related to efforts to achieve the 17 goals of the SDGs. What programs, efforts and activities have been carried out from each university and how big the impact is. Each university that participates in the ranking is confirmed to have an SDG Center or similar unit. Diponegoro University (Undip) already has an SDG Center, namely Unity (Undip Initiatives for Sustainability, [18] which is responsible for matters related to the SDGs. In 2019, Diponegoro University took second place in Indonesia in THE University Impact Ranking. We believe that the Diponegoro University campus should be an environmentally friendly campus, where students study comfortably, safely with a clean and healthy campus [19].

The second ranking related to SDGs is the UI Greenmetric World University Ranking which began in 2010. Currently, 780 universities have participated in the ranking worldwide from 85 countries. This ranking specifically looks at 6 aspects of management in each tertiary institution, namely, setting and infrastructure, energy and climate change, waste, water, transportation; and education and research. With various indicators that are very close to the 17 SDGs goals, universities that follow this ranking are certain to have implemented at least part of the programs that support the achievement of the SDGs [20,21]. 


\section{References}

1. Liverman, D.M., Dialogues in Human Geography, 2 (2018).

2. Panuluh, S. Fitri, M.R. Biefing Paper, 2 (2016).

3. Mawonde, A., Togo, M., Int. J.Sustainability in Higher Educ. 20,5 (2019)

4. Utama, Y.J., Ambariyanto, A., Zainuri, M., Darsono, D., Setyono, B. Putro, S.P., J. Physics: Conf. Ser..,1 (2018). IOP Publishing.

5. Zamora-Polo, F., Sánchez-Martín, J., Sustainability, 11, 15 (2019).

6. Zamora-Polo, F., Sánchez-Martín, J., Corrales-Serrano, M., Espejo-Antúnez, L., Sustainability, 11, 13 (2019).

7. Mori Junior, R., Fien, J., Horne, R., Sustainability: J. Record, 12, 2 (2019).

8. Priyadarshini, P., Abhilash, P.C., J. Cleaner Production, 247 (2020).

9. El-Jardali, F., Ataya, N., Fadlallah, R., Health Res, Policy and Systems, 16, 1 (2018).

10. Dian, S.A., Susanti, S., Mutaallimah, A., Rohmah, C., Bul. Bis.Manaj. 4, 1 (2018).

11. Anggorowati, E.L., Shinta, A.A.M., Nafi'ah, E.R., Lathif, S., Prosiding Seminar Nasional Pendidikan Biologi. (2020).

12. Utama, Y.J., Ambariyanto, A. IOP Conference Series: Earth and Environmental Science, 55, 1 IOP Publishing (2017)

13. Ambariyanto, A., Utama, Y.J., E3S Web of Conferences, 31 EDP Sciences (2018)

14. Pribadi, R.E. E-Journal Ilmu Hub. Int. 5, 3 (2015)

15. de Vega, C.A., Ojeda-Benítez, S., Ramírez-Barreto, M.E., Resources, Conservation and Recycling, 39, 3 (2003

16. Utama, Y.J., Ambariyanto, A., Syafrudin, Samudro, G.,. E3S Web of Conferences. 48 EDP Sciences. (2018)

17. Miqdad, M., Izzalqurny, T.R., Bisma. 13, 3 (2019).

18. Ambariyanto, A., Utama, Y.J., Budihardjo, M.A.,Purwanto, P., E3S Web of Conferences, 73 EDP Sciences. (2018).

19. Utama, Y.J., Purwanto., Ambariyanto, A., Advanced Science Letters, 23, 3 (2017)

20. Sari, R.F., Tjahyono, G., Evaluation in Higher Education, 6, 2 (2012)

21. Lauder, A., Sari, R.F., Suwartha, N., Tjahjono, G., J. Cleaner Production, 108 ( 2015) . 